\title{
Pollutant removal from mining processing wastewater by electrochemical method
}

\author{
Altunay S. ${ }^{1 *}$, Kiliç İ.H. ${ }^{1}$, Öden M.K. ${ }^{2}$ and Çakmak B. ${ }^{1}$ \\ ${ }^{1}$ Gaziantep University, Faculty of Science and Arts, Biology Department, Gaziantep, Turkey \\ 2Department of Environmental Protection Technology, Selcuk University, Sarayönü Vocational High School, Konya, Turkey \\ Received: 25/04/2021, Accepted: 20/05/2021, Available online: 26/05/2021 \\ *to whom all correspondence should be addressed: e-mail: semihaaltunay89@gmail.com \\ https://doi.org/10.30955/gnj.003683
}

\section{Graphical abstract}

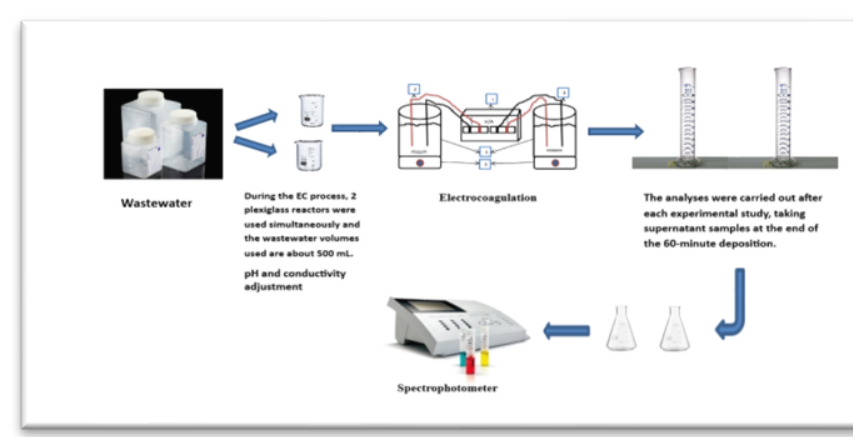

\begin{abstract}
Discharging wastewater from industries without any treatment causes environmental pollution and endangers biotic life. In this study, pollutant removal by electrocoagulation (EC) process was investigated using wastewater of the ore processing plant (magnesite crushing and screening plant). In the EC process, iron-iron and copper-copper electrodes were used in parallel in the reactor. Chemical oxygen demand (COD), Sulphate, Chromium (VI), Nickel, Zinc, Magnesium, and Total Suspended Solids (TSS) removals were investigated in the EC process of mineral processing industry wastewater with the iron electrode. These pollutants were calculated as \%97.6, \%95.1, \%98.2, \%98.1, \%97.8, \%88.2, and \%98.9, respectively. COD, Sulphate, Chromium (VI), Nickel, Zinc, Magnesium, and TSS removals in the EC process of mineral processing industry wastewater with the copper electrode are \%92.8, \%94.9, \%99.5, \%98.7, \%96.1, \%91.6, and \%96.9 respectively.

It has been observed that high removal efficiency can be achieved by using the electrocoagulation process in the treatment of ore washing wastewater resulting from the crushing and screening processes in the Chrome Magnesite processing plant.
\end{abstract}

Keywords: Electrocoagulation, magnesite, wastewater, removal, heavy metal.

\section{Introduction}

With the emergence of industrial transformation in our country and all over the world, there have been some industrial and technological changes and reforms. These developments have accelerated innovations and mechanization in every field in order to meet the basic and other needs of the increasing world population. While these new technology machines facilitate production, they also increase the amount of wastewater and the variety of pollutants. Permanent environmental problems occur as a result of the discharge of industrial wastewater to receiving environments without treatment (Oden, 2020).

The concept of heavy metal ions refers to elements with a specific gravity greater than 5.0, such as transition elements (Al-Qodah et al., 2017; Costa, 1997). Soils relating different aged igneous, metamorphic and sedimentary rocks, having different origins and chemical properties are exposed, in the Konya residential area (Horasan and Arik, 2019). Heavy metals such as chromium, copper, and cobalt are known to be toxic metals for living organisms and are the most common contaminants for the environment (James et al., 2006; Vinikour et al., 1980). Pollutants such as Zinc, Chromium, Nickel and Lead spread to the environment with the effect of mining and human activities pose an ecological risk (Horasan, 2020). Potential sources of these contaminants in industrial wastewater include metal cleaning and coating baths, pulp, cardboard factories, petrochemical industries, dyes and pigments, stormwater drainage, and mining activities (Boujelben et al., 2009; Kimbrough et al., 1999; Marshal, 1979; Naeem et al., 2009; Rengaraj and Moon, 2002; Seven ve ark, 2018). Heavy metals such as mercury, lead, chromium, nickel, copper, cadmium, and zinc are not biodegradable, highly toxic, and possibly carcinogenic.

In addition, most of the heavy metal ion salts are very soluble in aqueous solutions. Accordingly, it is not easy to separate these ions from aqueous solutions or wastewater using simple separation processes such as precipitation (Hussein et al., 2004). Furthermore, since these ions are persistent in the environment and do not decompose to form harmless products, it is important to purify and 
remove these toxic ions from all wastewater before being discharged into the environment (Egila et al., 2011; Sarı et al., 2009). For the removal of heavy metals from aqueous waste streams, adsorption (Lazaridis et al., 2005), biosorption (Senthikumar et al., 2010), ion exchange (Inglezakis et al., 2003), chemical precipitation (Kurniawan et al., 2006) are used. These treatment technologies require $\mathrm{pH}$ adjustment, high maintenance, high operating costs, a long operating time, and create large amounts of sludge, and secondary contamination. Therefore, alternative methods were needed to overcome and/or improve some of these problems. Electrochemical methods: electro acquisition (Bolger et al., 2004), electrodialysis (Marder et al., 2004), electrodeionization (Yeon et al., 2003) and various treatment processes such as electrocoagulation have been proposed due to costeffective maintenance and operation, such as high treatment performance, low sludge formation (Kobya et al., 2006; Kumar et al., 2004; Lakshmanan et al., 2010). In the EC process, sheet Al or Fe electrodes are commonly used for contaminant removal (Gomes et al., 2007; Kumar et al., 2004). However, these types of electrodes have some disadvantages due to their low surface area and processing difficulties (Sık et al., 2015).

Electrochemical methods offer many possibilities for wastewater treatment. In addition to the oxidation process, coagulation and precipitation processes can be used in the removal of targeted micro-pollutants (Udert et al., 2013). Electrochemical processes for pollution abatement have been proved viable alternatives or complementary to biological treatment in some instances, especially when pollutants are recalcitrant to biological processing (Stergiopoulos et al., 2013). The method called electrochemical coagulation, or electrocoagulation, does not use any chemicals as coagulants. These are produced by electrode dissolution of a sacrificial anode made of aluminum or iron during the electrolysis process. Iron and aluminum electrodes are widely used in the EC process (Suárez et al., 2016).

Treatment and improvement of textile wastewater (Dermentzis et al., 2011), landfill leachates (Kurtoğlu Akkaya and Bilgili, 2020), petroleum wastewater (Abdelwahab et al., 2009), diesel and biodiesel wastewater (Chavalparit et al., 2009), bleach (Wang et al., 2009), slaughterhouse wastewater (Asselin et al., 2008), arsenic or fluoride-containing wastewater (Hansen et al., 2007), heavy metal containing wastewater (Adhoum et al., 2004) and mine water from (Nariyan et al., 2017) electrocoagulation for purification and improvement has been successfully carried out. Electrocoagulation is an effective, reliable, and low-cost method to treat a wide variety of wastewater contents and is used for the removal of aqueous solutions containing chemical oxygen demand (COD), paint, oil, and grease from industrial and domestic wastewater (Adhoum and Monser, 2004; Hossini and Rezaee, 2014; ; Rezaee et al., 2012).

In this article, the efficiency achievement of Nickel, Chromium (VI), Zinc, Magnesium, Sulphate, TSS, and COD removal with different electrodes, different $\mathrm{pH}$ values, currents, and durations from the raw wastewater generated in the ore preparation phase (crushing screening plant) of the Chrome Magnesite plant were investigated. As a result of the literature reviews, it is important for the originality of the study, which has not been conducted before.

\section{Materials and methods}

\subsection{Characterization of crushing screening ore washing wastewater}

The wastewater used in this study was obtained during the ore preparation phase (crushing and screening plant) of the Chromium Magnesite plant in Konya province in Turkey and stored at $+4{ }^{\circ} \mathrm{C}$. As a first step, the properties of raw wastewater were determined. Crushing and screening plant wastewater characterization is shown in Table 1.

Table 1. Characterization of ore washing wastewater of crushing screening plant

\begin{tabular}{cc}
\hline Parameters & Measurement value (mg/L) \\
\hline $\mathrm{pH}$ & 8,5 \\
\hline Conductivity, $\mu \mathrm{S} / \mathrm{cm}$ & 395 \\
\hline $\mathrm{COD}$ & 103 \\
\hline Chromium $(\mathrm{VI})\left(\mathrm{Cr}^{+6}\right)$ & 10 \\
\hline Boron ( B) & 1,21 \\
\hline Nitrate $\left(\mathrm{NO}_{3}{ }^{-}\right)$ & 10,2 \\
\hline Sulfate $\left(\mathrm{SO}_{4}{ }^{2-}\right)$ & 767 \\
\hline Aluminum $(\mathrm{Al})$ & 1,39 \\
\hline Nitrite $\left(\mathrm{NO}_{2}{ }^{-}\right)$ & 2,26 \\
\hline Zinc $(\mathrm{Zn})$ & 5,74 \\
\hline Nickel $(\mathrm{Ni})$ & 10,3
\end{tabular}

Contaminant analyzes were performed using the Hach Lange DR 3900 Spectrophotometer in accordance with appropriate methods. Other analyzes were performed according to Standart Methods (APHA, 2017).

\subsection{Experimental setup and procedure}

Schematics of the experimental equipment for the EC process are shown in Figure 1. A laboratory-scale EC reactor was made of Plexiglass $9 \mathrm{~cm}$ in diameter and $13 \mathrm{~cm}$ in length. Consisting of an anode and a cathode, Iron and copper electrodes consisting of anode and cathode were used as altruistic electrodes of $6 \mathrm{~cm}$ width, $12 \mathrm{~cm}$ height and $0.1 \mathrm{~cm}$ thickness, continuously cleaned with distilled water. The total effective electrode surface area was fixed at $150 \mathrm{~cm}^{2}$ and the distance between the electrodes was $1.5 \mathrm{~cm}$. In EC experiments, a digital DC power supply with a current density of 0-30 V / 0-5 A was used (MERVESAN DC POWER SUPPLY) to apply the current density.

During the EC process, 2 plexiglass reactors were used simultaneously and the wastewater volumes used are about $500 \mathrm{~mL}$. A magnetic mixer was used to shake wastewater at $100 \mathrm{rpm}$. After EC, the layer formed on the surface of the electrode was cleaned with pure water and weighed on the sensitive scale and the electrode losses were calculated. $\mathrm{HCl}$ and $\mathrm{NaOH}(0.1 \mathrm{~N}-1 \mathrm{~N})$ solutions were used when adjusting the $\mathrm{pH}$ in the reactor, and $\mathrm{NaCl}$ was used at the required doses when adjusting the conductivity. EC experiments were conducted under conditions of $\mathrm{pH} 3-8.5$, a current density of 10.67-42.67 $\mathrm{mA} / \mathrm{cm}^{2}$, and a reaction time of $10-40$ minutes. The 
analyses were carried out after each experimental study, taking supernatant samples at the end of the 60-minute deposition. Supernatant samples were stored in $50 \mathrm{ml}$ glass bottles at $+4^{\circ} \mathrm{C}$.

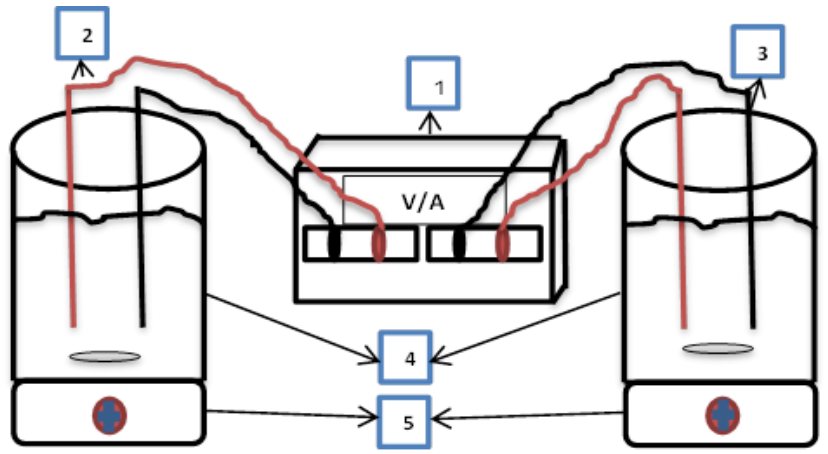

Figure 1. EC Reactor Assembly (1: Power Supply, 2: Anode Electrode, 3: Cathode Electrode, 4: Reactor, 5: Magnetic mixer)

\section{Results and discussion}

In the experiments carried out to determine the most suitable conditions for maximum pollutant removal, variables such as electrode type, $\mathrm{pH}$, contact time, and current density were used.

\subsection{Effect of different $\mathrm{PH}$ values on pollutant removal}

By using Fe-Fe and $\mathrm{Cu}-\mathrm{Cu}$ electrodes, contact time (20 min) and current density $\left(16 \mathrm{~mA} / \mathrm{cm}^{2}\right)$ are kept constant; Nickel, Chromium (VI), Zinc, Magnesium, Sulphate, TSS, and COD contaminant removal efficiencies at $\mathrm{pH} \mathrm{3,5,7}$ and 8.5 (original $\mathrm{pH}$ ) values were investigated. Pollutant removal percentages are given in Figure 2 for the iron electrode and Figure 3 for the Copper electrode.

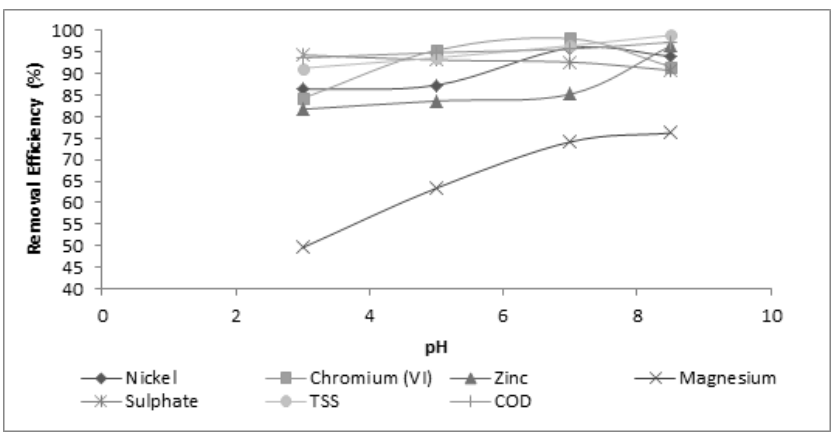

Figure 2. The effect of different $\mathrm{pH}$ values on pollutant removal. Experimental conditions: Fe electrode, Contact time: $20 \mathrm{~min}$, Current Density $16 \mathrm{~mA} / \mathrm{cm}^{2}$

As shown in Figure 2, maximum Nickel and Chromium (VI) removal efficiencies were $\% 96.02, \% 98.20$ in the use of iron electrodes at $\mathrm{pH}$ 7. Maximum, Zinc, Magnesium, TSS, COD removal efficiencies were \%96.46, \%76.24, \%96.98, \%97.35 at $\mathrm{pH} 8.5$.

As can be seen in Figure 3, in the use of copper electrodes, Maximum Sulfate removal efficiency was \%94.37 at pH 3 . Maximum Nickel, Chromium (VI), Magnesium, TSS and COD removal efficiencies were $\% 93.59, \% 98.14, \% 90.74, \% 96.43$ and $\% 92.85$ at $\mathrm{pH}$ 8.5. The maximum Zinc removal efficiency was \%88.54 at $\mathrm{pH}$ 7. The removal of zinc removal efficiency at high $\mathrm{pH}$ and high efficiency indicates that hydroxide precipitation is dominant (Matlock et al., 2002). The maximum sulfate removal efficiency was \%94.97 at pH 5.

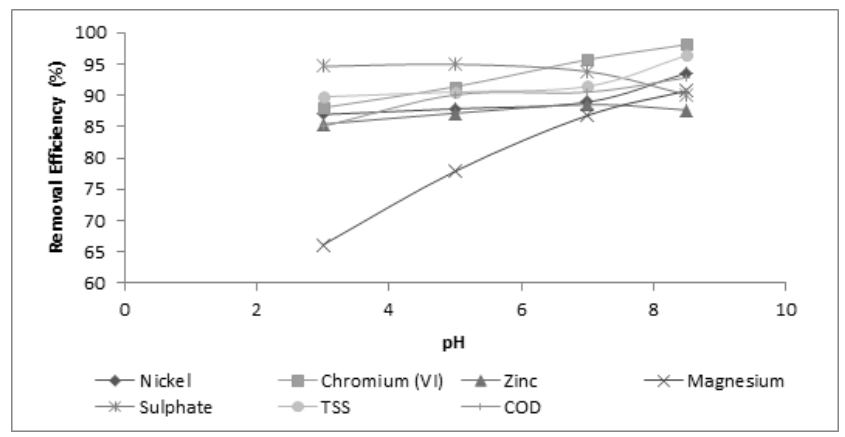

Figure 3. The effect of different $\mathrm{pH}$ values on pollutant removal. Experimental conditions: $\mathrm{Cu}$ electrode, Contact time: $20 \mathrm{~min}$, Current Density $16 \mathrm{~mA} / \mathrm{cm}^{2}$

In a study, increases in pollutant removal efficiency were observed with the increase in $\mathrm{pH}$. Providing high removal efficiency at high $\mathrm{pH}$ indicates that metal ions are removed mainly by precipitation in the form of hydroxides (Beyazit, 2014). However, the effect of $\mathrm{pH}$ on heavy metal ions removal usually differs according to the particular application. This effect could depend on the anode used, type of pollutant, and the reaction mechanism between them.

It has been determined that the $\mathrm{pH}$ value of our raw wastewater is 8.5 , there is no need for an additional chemical addition, and the optimum pH is 8.5 considering the maximum pollution removal efficiencies by using the data of Figures 2 and 3.

\subsection{Effect of different current density values on pollutant removal}

Using Fe-Fe and Cu-Cu electrodes, keeping contact time (20 min) and optimum $\mathrm{pH} 8.5$ constant, at different current densities $\left(10.67 \mathrm{~mA} / \mathrm{cm}^{2}, 16 \mathrm{~mA} / \mathrm{cm}^{2}, 21.3 \mathrm{~mA} / \mathrm{cm}^{2}, 26.67\right.$ $\mathrm{mA} / \mathrm{cm}^{2}, 32 \mathrm{~mA} / \mathrm{cm}^{2}, 37.33 \mathrm{~mA} / \mathrm{cm}^{2}$ and $42.67 \mathrm{~mA} / \mathrm{cm}^{2}$ ) Nickel, Chromium (VI), Zinc, Magnesium, Sulphate, TSS and COD pollutant removal efficiencies were investigated. Pollutant removal percentages are given in Figure 4 for the iron electrode and Figure 5 for the copper electrode.

As can be seen in Figure 4, in the use of iron electrodes; Maximum Nickel removal efficiency was \%98.14 at a current density of $21.3 \mathrm{~mA} / \mathrm{cm}^{2}$. Maximum Chromium (VI) removal efficiency was $\% 97.50$ at a current density of $26.67 \mathrm{~mA} / \mathrm{cm}^{2}$. Maximum Zinc and COD removal efficiency were \%88.72 and \%97.65 at a current density of 16 $\mathrm{mA} / \mathrm{cm}^{2}$. The maximum magnesium removal efficiency was $\% 86.84$ at a current density of $42.67 \mathrm{~mA} / \mathrm{cm}^{2}$. Maximum Sulphate and TSS removal efficiency were $\% 94.37 ; \% 98.85$ relatively at a current density of $10.67 \mathrm{~mA} / \mathrm{cm}^{2}$. 


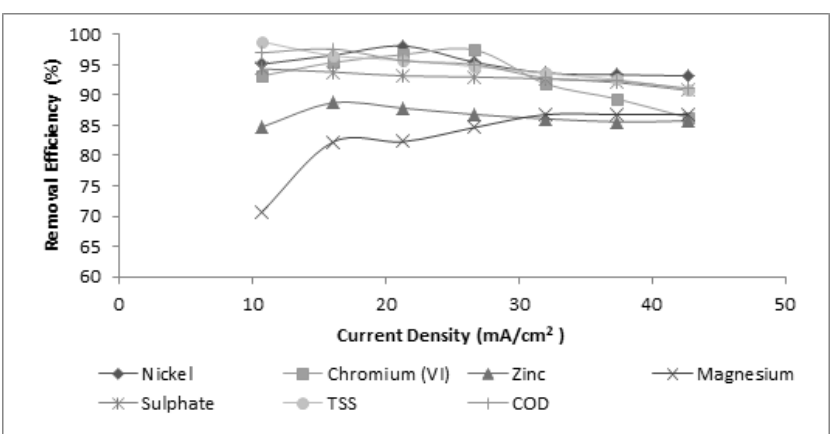

Figure 4. The effect of different current density values on pollutant removal. Experimental conditions: Fe electrode, Contact time: $20 \mathrm{~min}, \mathrm{pH}: 8.5$

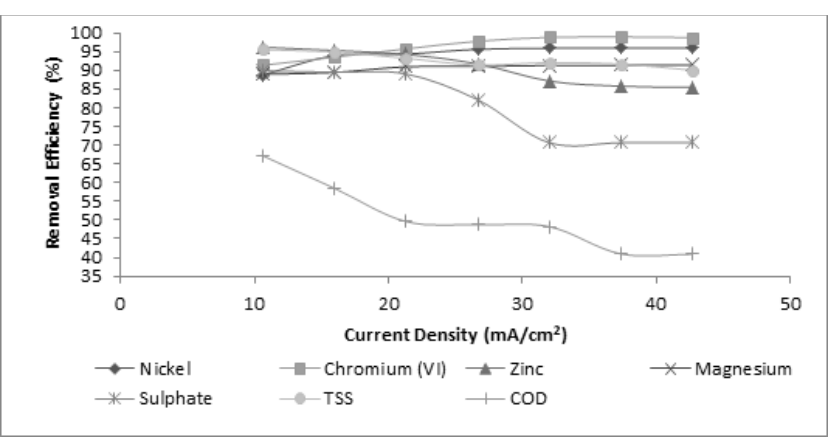

Figure 5. The effect of different current density values on pollutant removal. Experimental conditions: Cu electrode, Contact time: $20 \mathrm{~min}, \mathrm{pH}: 8.5$

As can be seen in Figure 5, in the use of copper electrodes; Maximum Nickel and Chromium (VI) removal efficiency were \%95.94, \%98.94, at a current density of 37.33 $\mathrm{mA} / \mathrm{cm}^{2}$. Maximum Zinc, Sulphate, TSS, and COD removal efficiency were $\% 96.18, \% 89.87, \% 95.53, \% 67.09$ relatively at a current density of $10.67 \mathrm{~mA} / \mathrm{cm}^{2}$. The maximum magnesium removal efficiency was obtained as $\% 91.43$ at a current density of $42.67 \mathrm{~mA} / \mathrm{cm}^{2}$.

Current density directly affects the rate of coagulant formation, bubble size, and the formation of large agglomerates that allow contaminant removal (Wang and Chou, 2009).

Secondary reactions may occur at high current values and cause colloids to dissipate (Harif and Adin, 2011). It has been observed that as the current density increases, the water in the process heats up, which negatively affects flocculation. Consequently, and by using the data of Figures 4 and 5 . when the maximum pollution removal efficiencies are taken into consideration, it was determined that the optimal current density was $16 \mathrm{~mA} / \mathrm{cm}^{2}$ for the $\mathrm{Fe}$ electrode and $21.3 \mathrm{~mA} / \mathrm{cm}^{2}$ for the Cu electrode.

\subsection{Effect of different time values on pollutant removal}

Using Fe-Fe and Cu-Cu electrodes at optimum $\mathrm{pH}$ of 8.5, optimum current density for Fe electrode and different contact times (0-40 minutes), Nickel, Chromium (VI), Nickel, Zinc, Magnesium, Sulphate, TSS, and COD removal efficiencies were examined. As a result of these expenses, Figures 6 and 7 were created.

As can be seen in Figure 6; Maximum Nickel, Zinc, Magnesium, TSS removal efficiency were \%90.23, \%97.80, $\% 88.24, \% 96.55$ in $40 \mathrm{~min}$ contact time. Maximum
Chromium (VI) and Sulphate removal efficiency were $\% 96.40, \% 95.15$ in 10 min contact time. The maximum COD removal efficiency was $\% 97.52$ in 20 min contact time.

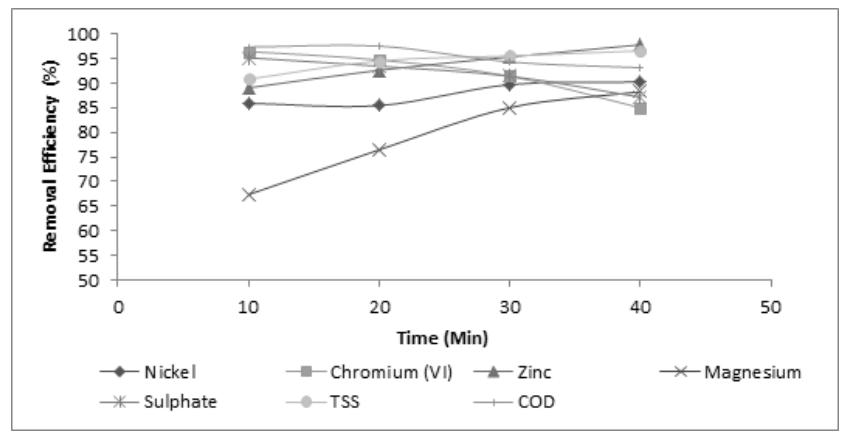

Figure 6. Effect of different contact times on pollutant removal. Experimental conditions: Fe electrode, $\mathrm{pH}$ : 8.5, current density $16 \mathrm{~mA} / \mathrm{cm}^{2}$

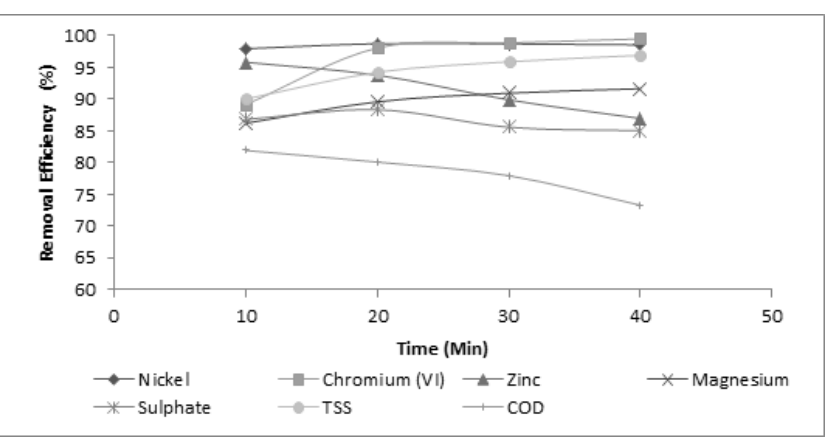

Figure 7. Effect of different contact times on pollutant removal. Experimental conditions: $\mathrm{Cu}$ electrode, $\mathrm{pH}$ : 8.5, current density $21.3 \mathrm{~mA} / \mathrm{cm}^{2}$

As seen in Figure 7; Maximum Nickel and Sulphate removal efficiency were \%98.77, \%88.36 in 20 min contact time. Maximum Chromium (VI), Magnesium, and TSS removal efficiency were \%99.51, \%91.67, \%96.94 in 40 min contact time. Maximum Zinc and COD removal efficiency were $\% 95.83, \% 81.93$ in 10 min contact time.

Considering the maximum impurity removal efficiencies by using the data of Figures 6 and 7 in the time optimization, it was determined that the optimal contact time was 20 minutes for the FE electrode and 30 minutes for the $\mathrm{Cu}$ electrode. Sufficient coagulant formation cannot be achieved when the contact time is kept short. However, when the contact time is kept long, decreases in efficiency have been observed due to the deterioration of the flocks. In a study with Al electrode, similar results were obtained in COD and Chromium removal efficiency depending on time (Daniel Villalobos-Lara et al., 2021).

\subsection{Comparison of obtained results with literature data}

The performance of the EC process depends on various factors such as current density, type of electrode material and distance between electrodes, initial $\mathrm{pH}$ of the wastewater, and treatment time. However, the main factors are current density, reaction time, and $\mathrm{pH}$ (AlQodah and Al-Shannag, 2017; Gomes et al., 2007; Kobya et al., 2011a, 2011b). The initial pH of wastewater is an important variable and often strongly affects the efficiency of contaminant removal. During the EC process, the $\mathrm{pH}$ changes, so it mostly refers to the initial $\mathrm{pH}$ of the 
wastewater. However, the effect of $\mathrm{pH}$ on the removal efficiency of heavy metals is application-specific (Adhoum et al., 2004; Basha et al., 2008; Heidmann and Calmano, 2008). It has been shown in the literature that the removal of heavy metals can be performed at various initial $\mathrm{pH}$ values ranging from 2.4 to 8 (Gomes et al., 2007; Hamdan and El-Naas, 2014; Kobya et al., 2011a, 2011b; Song et al., 2016). It has been determined that the $\mathrm{pH}$ value of our raw wastewater is 8.5. On the other hand, the current density is another important parameter and plays a vital role in EC performance. The range of density values available varies and depends on various factors such as the type and amount of contaminants to be removed from the wastewater. The results of previous studies show that the applied current density values vary between 2 and 400A / $\mathrm{m}^{2}$ and the typical values of the current density applied to remove heavy metal ions are between 4 and $80 \mathrm{~mA} / \mathrm{cm}^{2}$ (Al-Qodah and Al-Shannag, 2017; Gomes et al., 2007; Song et al., 2016). Determined that the optimal current density

Table 2. Comparison of results with previous studies

\begin{tabular}{|c|c|c|c|c|c|c|c|c|c|c|}
\hline \multirow[b]{2}{*}{ References } & \multirow[b]{2}{*}{$\begin{array}{l}\text { Water } \\
\text { types }\end{array}$} & \multirow[b]{2}{*}{ Pollutants } & \multirow[b]{2}{*}{ Electrodes } & \multicolumn{5}{|c|}{ Parameters considered } & \multicolumn{2}{|c|}{ Results } \\
\hline & & & & $\begin{array}{c}\mathrm{C}_{0} \\
(\mathrm{mg} / \mathrm{L})\end{array}$ & $\begin{array}{l}\text { Conductivity } \\
(\mathrm{mS} / \mathrm{cm})\end{array}$ & $\begin{array}{c}\mathrm{J} \\
\left(\mathrm{mA} / \mathrm{cm}^{2}\right)\end{array}$ & pH & $\begin{array}{c}t \\
(\min )\end{array}$ & $\begin{array}{c}\text { ENC } \\
\left(\mathrm{kWh} / \mathrm{m}^{3}\right)\end{array}$ & $\operatorname{Re}(\%)$ \\
\hline $\begin{array}{c}\text { Akbal and } \\
\text { Camci } \\
(2012)\end{array}$ & Real & $\mathrm{Cr}, \mathrm{Ni}, \mathrm{Cu}$ & Fe-Al $\times 6$ & $\begin{array}{l}193 \\
526 \\
335 \\
\end{array}$ & 4 & $2 \mathrm{~A}$ & 3 & 20 & - & $\begin{array}{c}100,100 \\
100\end{array}$ \\
\hline $\begin{array}{l}\text { Kabuk et } \\
\text { al. (2014) }\end{array}$ & Real & $\begin{array}{l}\mathrm{COD}, \mathrm{Cr} \\
\mathrm{Ni}, \mathrm{Zn}, \mathrm{Cu}\end{array}$ & Al-Al $\times 2$ & $\begin{array}{c}2960 \\
325 \\
125 \\
145 \\
91.5\end{array}$ & - & 25 & 8 & 90 & 225 & $\begin{array}{c}90,75,90 \\
100,97\end{array}$ \\
\hline $\begin{array}{l}\text { Al-Shannag } \\
\text { et al. } \\
\text { (2015) }\end{array}$ & Real & $\begin{array}{c}\mathrm{Cr}, \mathrm{Ni}, \mathrm{Zn}, \\
\mathrm{Cu}\end{array}$ & $\begin{array}{c}\text { Çelik-Çelik } \\
\text { x } 6\end{array}$ & $\begin{array}{l}93.2 \\
57.6 \\
20.4 \\
33.3 \\
\end{array}$ & 8.9 & 4 & 9.56 & 45 & 6.25 & $\begin{array}{l}>97 \text { for all } \\
\text { parameters }\end{array}$ \\
\hline $\begin{array}{c}\text { Oden and } \\
\text { Sari-Erkan } \\
(2018)\end{array}$ & Real & $\begin{array}{c}\text { COD, } \\
\text { Color, } \mathrm{Cr} \text {, } \\
\mathrm{Ni}, \mathrm{Zn}\end{array}$ & Fe-Fe $\times 2$ & $\begin{array}{c}475 \\
5983 \\
358 \\
8.1 \\
149.3 \\
\end{array}$ & 17.1 & - & $<2$ & 30 & - & $\begin{array}{l}>90 \text { for all } \\
\text { parameters }\end{array}$ \\
\hline $\begin{array}{l}\text { Oden } \\
(2020)\end{array}$ & Real & $\begin{array}{c}\mathrm{COD}, \mathrm{Cu} \\
\mathrm{Ni}\end{array}$ & Fe-Al $\times 2$ & $\begin{array}{c}32.350, \\
77.5 \\
54.8 \\
\end{array}$ & 1756 & - & $<9$ & 30 & - & $\begin{array}{l}>90 \text { for all } \\
\text { parameters }\end{array}$ \\
\hline $\begin{array}{c}\text { A. Daniel } \\
\text { Villalobos- } \\
\text { Lara et al. } \\
(2021) \\
\end{array}$ & Real & $\begin{array}{c}\text { COD, TSS, } \\
\text { Cr, }\end{array}$ & Al-Al x 6 & $\begin{array}{c}14000 \\
6000 \\
25\end{array}$ & 50 & - & 7 & 40 & 1.98 & $\begin{array}{c}70,>90 \\
>90\end{array}$ \\
\hline This study & Real & $\begin{array}{c}\mathrm{COD}, \\
\mathrm{SO}_{4}{ }^{2-}, \mathrm{Cr} \\
(\mathrm{VI}), \mathrm{Ni}, \\
\mathrm{Zn}, \mathrm{Mg}, \\
\mathrm{TSS}\end{array}$ & $\begin{array}{l}\text { Fe-Fe } \times 2 \\
\text { Cu-Cu } \times 2\end{array}$ & $\begin{array}{c}103 \\
767 \\
10 \\
10.3 \\
5.76 \\
48.40 \\
0.273\end{array}$ & 395 & - & 8.5 & $\begin{array}{l}20- \\
30\end{array}$ & - & $\begin{array}{l}>85 \text { for all } \\
\text { parameters }\end{array}$ \\
\hline
\end{tabular}

was $16 \mathrm{~mA} / \mathrm{cm}^{2}$ for the Fe electrode and $21.3 \mathrm{~mA} / \mathrm{cm}^{2}$ for the $\mathrm{Cu}$ electrode. The last important operating parameter, the reaction or treatment time, and the efficiency of removal of contaminants depend significantly on the reaction time, as coagulant production from the anode increases with time. The efficiency of pollutant removal increases with increasing reaction time until it reaches the maximum value in the optimum reaction time. Many authors have found that the optimum time values in the literature for removal of heavy metals are between 10 and 60 minutes (Akbal and Camci, 2010; Gomes et al., 2007; Hamdan and El-Naas, 2014; Kobya et al., 2015; Song et al., 2016). Time optimization, it was determined that the optimal contact time was 20 minutes for the FE electrode and 30 minutes for the $\mathrm{Cu}$ electrode. The results of previous studies on the removal of COD and heavy metals in wastewater from the crushing and screening plant using the EC method are summarized in Table 2.

\section{Conclusions}

In this study, the effect of electrode type, electrolysis time, wastewater $\mathrm{pH}$, and current density on pollutant removal from the wastewater of the ore processing plant (magnesite fracking and screening plant) in the electrocoagulation process with the use of $\mathrm{Fe}$ and $\mathrm{Cu}$ electrodes was investigated. As a result of the researches, it is seen that the variables of current density, electrolysis time, and $\mathrm{pH}$ affect the removal efficiency at the central level. High pollutant removal efficiencies were obtained 
under optimum conditions. As a result of the experiments, the following results were obtained:

> Nickel, Chromium (VI), Zinc, Magnesium, Sulphate, AKM and COD removal efficiencies under optimum conditions; \%96,60, \%98,20, \%97,80, \%88,24, $\% 95,15, \% 98,98$ and $\% 97,65$ on iron electrode; $\% 98,77, \% 99,51, \% 96,18, \% 91,67, \% 94,97, \% 96,94$ ve $\% 92,85$ on copper electrode.

$>$ The wastewater produced in the crushing and screening meets the specified direct discharge limit value of turkey Water Pollution Control Regulation (COD $<80 \mathrm{mg} / \mathrm{L}$, zinc $<3 \mathrm{mg} / \mathrm{L}$, the total chromium $<2 \mathrm{mg} / \mathrm{L}$ ) (Environment and Urban Ministry), and in this experimental study, high COD, TSS, Zinc, the Chromium removal efficiency was obtained and this wastewater was made less harmful.

$>$ Electrocoagulation with Iron and Copper electrodes is a safe, reliable, convenient, and efficient way of removal. The highest removal efficiency for the removal of heavy metals such as COD, Sulphate, Chromium (VI), Nickel, Zinc, Magnesium, and TSS in the wastewater of the ore processing plant (magnesite crushing and screening plant) is $\mathrm{pH} 8.5$ for iron electrode, current density of $16 \mathrm{~mA} / \mathrm{cm}^{2}, 20$ min contact time; for copper electrode, it is $\mathrm{pH} 8.5$, current density of $21.3 \mathrm{~mA} / \mathrm{cm}^{2}, 30 \mathrm{~min}$ contact time. It has been observed that it is a good treatment method by achieving pollutant removal efficiency of over $85 \%$ under the optimum conditions found.

$>$ It is also valuable in that the data obtained are obtained as a result of real wastewater treatment. These data will shed light on the treatment of mining industry wastewater and help design industrial-type treatment plants.

$>$ The EC process depends on electrical energy generated from non-renewable sources. This has disadvantages such as high operating costs and indirect pollution caused by burning fossil fuels to generate electricity. To eliminate these disadvantages, it is necessary to use sustainable renewable energy sources such as wind or tidal energy, photovoltaic modules (Dominguez-Ramos et al., 2010), or biogas produced from anaerobic fermentation of waste materials (Fernandes et al., 2015).

$>$ The anode and cathode are the most important parts of the EC cell system. However, in most cases, the anode suffers from rapid consumption and the electrode undergoes passivation. For this, further research should be conducted to improve the performance of both electrodes and to use new electrode materials containing more cost-effective electrodes (Fernandes et al., 2015).

$>$ More extensive research is needed in the areas of process optimization, modeling, scale-up, and process integration to prove the reliability of this technology for large-scale wastewater treatment.

\section{Acknowledgment}

I would like to thank Gaziantep University BAP Management Unit (FEF.YLT.20.05 project) for providing financial support in this study and Mining Engineer Hasan ESER for their support in the supply of raw wastewater to be used in the research study.

\section{References}

Abdelwahab O., Amin N.K. and El-Ashtoukhy E-S.Z. (2009), Electrochemical removal of phenol from oil refinery wastewater, Journal of Hazardous Materials, 163, 711-716.

Adhoum N., Monser L., Bellakhal N. and Belgaied J-E. (2004), Treatment of electroplating wastewater containing $\mathrm{Cu} 2+$, $\mathrm{Zn} 2+$ and $\mathrm{Cr}(\mathrm{VI})$ by electrocoagulation, Journal of Hazardous Materials, B112, 207-213.

Akbal F. and Camci S. (2010), Comparison of electrocoagulation and chemical coagulation for heavy metal removal, Chemical Engineering \& Technology, 33, 1655-1664.

Akbal F. and Camci S. (2011), Copper, chromium and nickel removal from metal plating wastewater by electrocoagulation, Desalination, 269, 214-222.

Akbal F. and Camci S. (2012), Treatment of metal plating wastewater by electrocoagulation, Environmental Progress \& Sustainable Energy, 31, 340-350.

Al-Qodah Z. and Al-Shannag M. (2017), Heavy metal ions removal from wastewater using electrocoagulation processes: a comprehensive review, Separation Science and Technology, 52, 2649-2676.

Al-Qodah Z., Al-Shannag M., Amro A., Assiri E., Mustafa B., BaniMelhem K. and Kasrawi M.A. (2017), Impact of surface modification of green algal biomass by phosphorylation on the removal of copper (II) ions from water. Turkish Journal of Chemistry, 41: 190-208.

Al-Shannag M., Al-Qodah Z., Bani-Melhem K., Qtaishat M.R. and Alkasrawi M. (2015), Heavy metal ions removal from metal plating wastewater using electrocoagulation: kinetic study and process performance, Chemical Engineering Journal, 260, 749-756.

APHA. (2017), Standard Methods for the Examination of Water and Wastewater, American Public Health Association, American Water Works Association, Water Environment Federation.

Asselin M., Drogui P., Benmoussa H. and Blais J-F. (2008), Effectiveness of electrocoagulation process in removing organic compounds from slaughterhouse wastewater using monopolar and bipolar electrolytic cells, Chemosphere, 72, 1727-1733.

Basha C.A., Bhadrinarayana N.S., Anantharaman N. and Begum K.M.M.S. (2008), Heavy metal removal from copper smelting effluent using electrochemical cylindrical flow reactor, Journal of Hazardous Materials, 152, 71-78.

Bazrafshan E., Mohammadi L., Ansari-Moghaddam A. and Mahvi A.H. (2015), Heavy metals removal from aqueous environments by electrocoagulation process-a systematic review. Journal of Environmental Health Science and Engineering, 13, 1.

Beyazit N. (2014), Copper(II), Chromium(VI) and Nickel(II) Removal from Metal Plating Effluent by Electrocoagulation, International Journal of Electrochemical Science, 9, 43154330.

Bhagawan D., Poodari S., Pothuraju T., Srinivasulu D., Shankaraiah G., Rani M.Y., Himabindu V. and Vidyavathi S. (2014), Effect of 
operational parameters on heavy metal removal by electrocoagulation, Environmental Science and Pollution Research, 21, 14166-14173.

Bhattacharya A., Mandal S. and Das S. (2006) Adsorption of Zn (II) from aqueous solution by using different adsorbents. Chemical Engineering Journal, 123, 43-51.

Bolger P.T. and Szlag D.C. (2004), Electrochemical treatment and reuse of nickel plating rinse waters, Environmental Progress, 21, 203-208.

Boujelben N., J. Bouzid and Z. Elouear. (2009), Adsorption of Nickel and Copper onto Natural Iron Oxide-coated Sand from Aqueous Solutions: Study in Single and Binary Systems. Journal of Hazardous Material, 163, 376-82.

Chavalparit O. and Ongwandee M. (2009), Optimizing electrocoagulation process for the treatment of biodiesel wastewater using response surface methodology, Journal of Environmental Sciences, 21, 1491-1496.

Costa M. (1997) Toxicity and carcinogenicity of $\mathrm{Cr}$ (VI) in animal models and humans. Critical Reviews in Toxicology, 27, 431-442.

Dermentzis K., Marmanis D., Valsamidou E., Christoforidis A. and Ouzounis K. (2011), Electrochemical decolorization treatment of nickel phthalocyanine reactive dye wastewater, Environmental Engineering and Management Journal, 10, 1703-1709.

Dominguez-Ramos A., Aldaco R. and Irabien A. (2010) Photovoltaic solar electrochemical oxidation (PSEO) for treatment of lignosulfonate wastewater. Journal of Chemical Technology and Biotechnology, 85, 821-830.

Egila J., Dauda B., Iyaka Y. and Jimoh T. (2011), Agricultural waste as a low cost adsorbent for heavy metal removal from wastewater. International Journal of Physical Sciences, 6, 2152-2157.

Fernandes A., Pacheco M., Ciríaco L. and Lopes A. (2015), Review on the electrochemical processes for the treatment of sanitary landfill leachates: present and future. Applied Catalysis B: Environmental, 176, 183-200.

Gadd G.M. (2010), Metals, minerals and microbes: geomicrobiology and bioremediation. Microbiology, 156, 609-643.

Gomes J.A.G., Daida P., Kesmez M., Weir M., Moreno H., Parga J.R., Irwin G., McWhinney H., Grady T., Peterson E. and Cocke D.L. (2007), Arsenic removal by electrocoagulation using combined $\mathrm{Al}-\mathrm{Fe}$ electrode system and characterization of products. Journal of Hazardous Materials, 139(2), 220-231.

Hamdan S.S. and El-Naas M.H. (2014), An electrocoagulation column (ECC) for groundwater purification, Journal of Water Process Engineering, 4, 25-30.

Hansen H.K., Nunez P., Raboy D., Schippacase I. and Grandon R. (2007), Electrocoagulation in wastewater containing arsenic: Comparing different process designs, Electrochimica Acta, 52, 3464-3470.

Harif T. and Adin A. (2011), Size and structure evolution of kaolinAl $(\mathrm{OH}) 3$ flocs in the electroflocculation process: a study using static light scattering. Water Research, 45, 6195-6206.

Heidmann I. and Calmano W. (2008), Removal of $\mathrm{Zn}(\mathrm{II}), \mathrm{Cu}(\mathrm{II})$, $\mathrm{Ni}(\mathrm{II}), \mathrm{Ag}(\mathrm{I})$ and $\mathrm{Cr}(\mathrm{VI})$ presentin aqueous solutions by aluminium electrocoagulation, Journal of Hazardous Materials, 152, 934-941.
Horasan B.Y. (2020), The environmental impact of the abandoned mercury mines on the settlement and agricultural lands; Ladik (Konya, Turkey). Environmental Earth Sciences, 79, 1-13.

Horasan B.Y. and Arik F. (2019), Assessing heavy metal pollution in the surface soils of Central Anatolia Region of Turkey, Carpathian Journal of Earth and Environmental Sciences, 14(1), 107-118.

Hussein H., Ibrahim S.F., Kandeel K. and Moawad H. (2004), Biosorption of heavy metals from wastewater using Pseudomonas sp. Electronic Journal of Biotechnology, 7, 30-37.

Inglezakis V.J., Loizidou M.D. and Grigoropoulou H.P. (2003), Ion exchange of $\mathrm{Pb}^{2+}, \mathrm{Cu}^{2+}, \mathrm{Fe}^{3+}$ and $\mathrm{Cr}^{3+}$ on natural clinoptilolite: selectivity determination and influence on activity on metal uptake, Journal of Colloid and Interface Science, 261, 49-54.

James R., K. Sampath and P. Selvamani. (2006), Effect of Ionexchanging Agent, Zeolite on Removal of Copper in Water and Improvement of Growth in Oreochromis mossambicus (Peters). Asian Fisheries Science, 13, 317-325.

Kabuk H.A., Avsar Y., Ilhan F. and Ulucan K. (2014), Comparison of $\mathrm{pH}$ adjustment and electrocoagulation processes on treatability of metal plating wastewater, Separation Science and Technology, 49, 613-618.

Kimbrough D.E., Y. Cohen A.M. Winer L. Creelman and C. Mabuni. (1999), A Critical Assessment of Chromium in the Environment, Critical Reviews on Environmental Science and Technology 29, 1-46.

Kobya M., Demirbas E., Bayramoglu M. and Sensoy M.T. (2011a). Optimization of electrocoagulation process for the treatment of metal cutting wastewaters with response surface methodology, Water, Air, \& Soil Pollution, 215, 399-410.

Kobya M., Demirbaş E., Cana O.T. and Bayramoğlu M. (2006), Treatment of levafix orange textile dye solution by electrocoagulation, Journal of Hazardous Materials, 132(2-3), 183-188.

Kobya M., Erdem N. and Demirbas E. (2015), Treatment of Cr, Ni and $\mathrm{Zn}$ from galvanic rinsing wastewater by electrocoagulation process using iron electrodes, Desalination Water Treat, 56, 1191-1201.

Kobya M., Ulu F., Gebologlu U., Demirbas E. and Oncel M.S. (2011b). Treatment of potable water containing low concentration of arsenic with electrocoagulation: different connection modes and Fe-Al electrodes. Separation and Purification Technology, 77, 283-293.

Kumar P.R., Chaudhari S., Khilar K.C. and Mahajan S.P. (2004), Removal of arsenic from water by electrocoagulation, Chemosphere, 55(9), 1245-1252.

Kurniawan A., Chan G.Y.S., Lo W-H. and Babel S. (2006), Physicochemical treatment techniques for wastewater laden with heavy metals, Chemical Engineering Journal, 118, 83-98.

Kurtoğlu Akkaya G. and Bilgili M.S. (2020), Evaluating the performance of an electro-membrane bioreactor in treatment of young leachate, Journal of Environmental Chemical Engineering, 8, 104017.

Lakshmanan D., Clifford D.A. and Samanta G. (2010), Comparative study of arsenic removal by iron using electrocoagulation and chemical coagulation, Water Research, 44(19), 5641-5652.

Lazaridis N.K., Bakayannakis D.N. and Deliyianni E.A. (2005), Chromium (VI) sorptive removal from aqueous solution by nano crystalline akaganeite, Chemosphere, 58, 65-73. 
Marder L., Bernardes A.M. and Ferreira J.Z. (2004), Cadmium electroplating wastewater treatment using a laboratory-scale electrodialysis system, Separation and Purification Technology, 37, 247-255.

Marshal S. (1979), Hazardous and Toxic Effects of Industrial Chemicals. New Jersey: NDC Publication.

Matlock M., Howerton B. and Atwood D. (2002), Chemical precipitation of heavy metals from acid mine drainage, Water Research, 36, 4757-4764.

Naeem A., Saddique M.T., Mustafa S., Tasleem S., Shah K.H. and WaseemM. (2009), Removal of $\mathrm{Co}^{2+}$ ions from aqueous solution by cation exchange sorption onto NiO. Journal of Hazardous. Material, 172, 124-8

Nariyan E., Sillanpaa M. and Wolkersdorfer C. (2017), Electrocoagulation treatment of mine water from the deepest working European metal mine - Performance, isotherm and kinetic studies. Separation and Purification Technology, 177, 363-373.

Oden M.K. (2020), Treatment of CNC industry wastewater by electrocoagulation technology: an application through response surface methodology. International Journal of Environmental Analytical Chemistry, 100(1), 1-19

Rengaraj S. and S.H. Moon. (2002), Kinetics of Adsorption of Co (II) Removal from water and wastewater by ion exchange resins. Water Research, 36, 1783-1793.

Sarı A. and Tuzen M. (2009), Biosorption of As (III) and As (V) from aqueous solution by macrofungus (Inonotus hispidus) biomass: equilibrium and kinetic studies. Journal of Hazardous Materials, 164, 1372-1378.

Senthikumar R., Vijaraghavan K., Jegan J. and Velan M. (2010), Batch and column removal of total chromium from aqueous solution using Sargassum polycystum, Environmental Progress and Sustainable Energy, 29, 334-341.

Seven T., Can B., Darende B. and Ocak S. (2018), Hava ve Toprakta Ağır Metal Kirliliği, Ulusal Çevre Bilimleri Araştırma Dergisi, 1(2), 91-103

Sik E., Kobya M., Demirbas E., Oncel M.S. and Goren A.Y. (2015), Removal of As (V) from groundwater by a new electrocoagulation reactor using Fe ball anodes: Optimization of operating parameters, Desalination and Water Treatment, 56(5), 1177-1190.

Singh H. and Rattan V. (2011) Adsorption of nickel from aqueous solutions using low cost biowaste adsorbents. Water Quality Research Journal of Canada, 46, 239-249.

Song P.P., Yang Z.H., Xu H.Y., Huang J., Yang X., Yue F. and Wang L.K. (2016), Arsenic removal from contaminated drinking water by electrocoagulation using hybrid Fe-Al electrodes: response surface methodology and mechanism study, Desalination Water Treat. 57, 4548-4556.

Stergiopoulos D., Dermentzis K., Giannakoudakis P. and Sotiropoulos S. (2014), Electrochemical decolorization and removal of Indigo Carmine textile dye from Wastewater, Global NEST Journal, 16, 499-506.

Suárez-Escobar A., Pataquiva-Mateus A. and A. López (2016) Vasquez, Catalysis Today, 266, 120.

Udert K.M., Brown-Malker S. and Keller J. (2013), Electrochemical systems. In: Source Separation and Decentralization for Wastewater Management. T.A. Larsen, K.M. Udert and J. Lienert (eds.), IWA Publishing, London, UK, pp. 321-335.

Wang C. and Chou W. (2009), Performance of COD removal from oxide chemical mechanical polishing wastewater using iron electrocoagulation, Journal of Environmental Science and Health Part, A44, 1289-1297.

Wang C-T., Chou W-L. and Kuo Y-M. (2009), Removal of COD from laundry wastewater by electrocoagulation/ electroflotation, Journal of Hazardous Materials, 164, 81-86.

Yeon K.H., Seong J.H., Rengaraj S. and Moon S.H. (2003), Electrochemical characterization of ionexchange resin beds and removal of cobalt by electrodeionization for high purity water production, Separation Science and Technology, 38, 443-462.

Zalloum H.M., Al-Qodah Z. and Mubarak M.S. (2008), Copper adsorption on chitosan-derived Schiff bases. Journal of Macromolecular Science, Part A, 46: 46-57. 